\title{
Perspektif mahasiswa terhadap kualitas "branding" perguruan tinggi
}

\section{Echo Perdana Kusumah *, Syamsu Yusuf}

Pascasarjana, Universitas Pendidikan Indonesia.

Jl. Dr. Setiabudi No. 229, Isola, Sukasari, Bandung, Jawa Barat 40154, Indonesia. echopk@upi.edu

* Corresponding Author

\section{ARTICLE INFO}

\section{Article History}

Received:

11 February 2020;

Revised:

16 June 2020;

Accepted:

19 June 2020

\section{Keywords}

Citra merek;

Konsep branding;

Kualitas;

Perguruan tinggi;

Brand image;

Concept of branding;

Quality;

Higher education;

\begin{abstract}
Konsep branding pada universitas dapat memberikan reputasi yang baik untuk universitas baik dari segi pelayanan maupun fasilitas yang diberikan kepada para calon mahasiswanya. Namun, penelitian mengenai konsep branding tersebut di Indonesia masih relatif terbatas. Melalui aspek sosial, penelitian ini bertujuan untuk menyelidiki dampak nilai-nilai yang dirasakan mahasiswa Universitas Bangka Belitung (nilai utilitas, nilai hedonic dan relasional atau hubungan) terhadap Kualitas Hubungan Merek (KHM) dengan merek institusional Universitas Bangka Belitung (UBB) serta pada akhirnya pada resonansi merek (RM). Sejumlah 250 sampel yang berlokasi di Universitas Bangka Belitung dapat diambil secara online menggunakan teknik convenience sampling dan data tersebut dianaliskan melalui Persamaan Model Struktural (SEM). Hasil menunjukkan bahwa seluruh faktor prediktif dapat mempengaruhi secara positif terhadap KHM dan KHM dapat memediasi hubungan faktor-faktor prediktif dan RM. Dengan roadmap merek yang dirancang dengan baik, universitas dapat menurunkan masalah salah interpretasi oleh calon mahasiswa yang dapat menggagalkan upaya pengembangan citra merek universitas di masa depan.
\end{abstract}

The concept of branding at universities can provide a good reputation for universities both in terms of services and facilities provided to prospective students. However, research on the concept of branding in Indonesia is still relatively limited. Through social aspects, this study aims to investigate the impact of perceived values of Bangka Belitung University students (utility value, hedonic value, and relational value) on Brand Relationship Quality (BRQ) with the institutional brand of Bangka Belitung University (UBB) and finally in Brand Resonance (BR). A total of 250 samples located at Bangka Belitung University can be taken online using convenience sampling techniques and the data is analyzed through Structural Model Equations (SEM). The results show that all predictive factors can positively influence the $B R Q$ and $B R Q$ can mediate the relationship between predictive factors and RM. With a well-designed brand roadmap, universities can reduce the problem of misinterpretation by prospective students that can thwart efforts to develop the university's brand image in the future.

This is an open access article under the CC-BY-SA license.

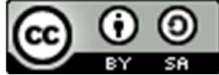

How to cite:

Kusumah, E. P., \& Yusuf, S. (2020). Perspektif mahasiswa terhadap kualitas "branding" perguruan tinggi. Jurnal Akuntabilitas Manajemen Pendidikan, 8(1), 24-33. doi:https://doi.org/10.21831/jamp.v8i1.30132 


\section{PENDAHULUAN}

Memahami proses penciptaan nilai bersama dalam jenis stimulus mental dari layanan seperti pendidikan tinggi sangat penting, karena keberhasilannya hanya dapat dicapai melalui keterlibatan dan hubungan peserta didik untuk ikut menciptakan layanan (Wæraas \& Solbakk, 2009). Menurut Robinson dan Celuch (2016), instansi pendidikan tinggi harus tetap sadar karena mahasiswa adalah pendukung yang menciptakan nilai asli dalam pemberian layanan pendidikan dan mahasiswa memainkan peran partisipatif aktif untuk berinteraksi dan bekerja secara kolaboratif dengan pendidik (Dollinger, Lodge, \& Coates, 2018). Selain itu, Fleischman, Raciti, dan Lawley (2015) menyarankan bahwa hubungan merek yang kuat diperlukan oleh instansi pendidikan tinggi untuk meningkatkan kesadaran akan keberadaan mereka. Diskusi tentang proses hubungan merek (brand) pelanggan, terutama dalam konteks layanan pendidikan tinggi, masih perlu dieksplorasi lebih lanjut.

Berbagai studi pada umumnya lebih difokuskan pada kepuasan mahasiswa (Balwin \& James, 2000), efektivitas komunikasi merek universitas (Klassen, 2002), kebijakan branding universitas (Goi \& Goi, 2009; Teh \& Aliah Hanim, 2011), dan komunikasi pemasaran inbound (Royo-Vela \& Hunermund, 2016). Namun, penyelidikan tentang proses dan bimbingan sistematis tentang bagaimana hubungan merek atau mahasiswa dikembangkan dan dikelola masih relatif terbatas. Secara teoritis, untuk mendukung diskusi tentang pembentukan hubungan merek pelanggan dalam layanan pendidikan tinggi, teori pertukaran sosial mengemukakan bahwa respons merek-pelanggan (konsekuensi) didorong oleh motivasi pertukaran nilai atau manfaat (anteseden), melalui ikatan psikologis (mediator) (Mitchell, Cropanzano, \& Quisenberry, 2012). Hal tersebut konsisten dengan penelitian Jayawardhena (2004), yang berpendapat bahwa nilai-nilai pelanggan memiliki efek tidak langsung pada perilaku konsumen melalui domain mediasi abstrak yang bersifat psikologis.

Dengan pemikiran tersebut, penelitian ini bertujuan untuk menyelidiki dampak nilai-nilai yang dirasakan mahasiswa Universitas Bangka Belitung (utilitas, hedonic, dan relasional atau hubungan) terhadap Kualitas Hubungan Merek (KHM) dengan merek institusional Universitas Bangka Belitung (UBB) dan pada akhirnya pada resonansi merek (RM). Selain itu, peran mediasi RM ditelusuri untuk memberikan penjelasan mendalam yang komprehensif tentang peran ikatan psikologis dalam membentuk hubungan merek mahasiswa dan universitas. Untuk tujuan penelitian ini, istilah 'nilai pelanggan' dapat diartikan sebagai 'nilai mahasiswa' yang digunakan secara bergantian. Selain itu, penelitian ini bertujuan untuk memberikan wawasan ke dalam artikulasi pembentukan hubungan merek pelanggan terutama pada pembentukan merek universitas. Dengan mengintegrasikan teori hubungan (relationship) dan teori pertukaran sosial, manajer merek terutama dalam layanan pendidikan tinggi, dapat memahami bagaimana hubungan pelanggan atau mahasiswa dan merek dapat dikembangkan. Lebih penting lagi, dengan meningkatnya minat universitas terhadap keberlanjutan bisnis di lingkungan yang kompetitif, pandangan tentang dampak jangka panjang dapat membantu universitas memahami peran hubungan merek dalam konteks pemasaran modern. Hal tersebut sangat penting untuk manfaat timbal balik kedua belah pihak (Brodie, Glynn, \& Little, 2006).

Jika terdapat kekurangan pada keterlibatan pelanggan atau mahasiswa untuk bersama-sama menciptakan layanan, hal itu dikarenakan kegagalan penyedia layanan untuk mengelola pembentukan hubungan merek pelanggan dan dapat menyebabkan respons merek yang tidak menguntungkan yang dapat merusak citra merek penyedia layanan tersebut (Kusumah, Hurriyati, \& Dirgantari, 2019). Terbukti dalam temuan Sternberg dan Sternberg (2018), ikatan psikologis menjadi konstruksi yang paling luas dan integratif dalam memahami sifat manusia. Ini karena, menurut teori pertukaran sosial, ikatan psikologis seseorang menetapkan beberapa kekuatan mendasar untuk mempengaruhi perilaku mereka (Graham, 2011). Dalam konteks pendidikan tinggi, Robinson dan Celuch (2016), menyoroti bahwa, Kualitas Hubungan Merek (KHM) mahasiswa yang dihasilkan dari ikatan psikologis yang kuat mengarah pada peningkatan loyalitas mahasiswa dan respon Resonansi Merek (RM), yang dapat membantu menjadi kunci variabel output untuk citra pendidikan tinggi. Sejalan dengan dukungan teoritis dan empiris, studi ini menghipotesiskan KHM memiliki hubungan positif dengan RM. Hipotesis pertama atau disingkat H1: KHM berpengaruh positif terhadap RM.

Teori pertukaran sosial menyoroti bahwa pemenuhan nilai-nilai pelanggan adalah pertimbangan utama pelanggan untuk tetap berada dalam suatu hubungan, karena tanpa itu, akan ada 
sedikit motivasi bagi pelanggan untuk melanjutkan hubungan pertukaran (Zafirovski, 2005). Dalam penjelasan lebih lanjut, Anand, Ward, dan Tatikonda (2010) menambahkan bahwa ada beberapa nilai yang dapat mempengaruhi ikatan psikologis dan perilaku pelanggan terhadap suatu merek; yang merupakan nilai hedonic, utilitarian dan relasional atau hubungan. Dalam konteks instansi pendidikan tinggi, persepsi nilai mahasiswa adalah penting terhadap pengalaman pendidikan secara keseluruhan, dan oleh karena itu sangat penting bagi lembaga untuk tetap kompetitif (Verghese \& Kamalanabhan, 2015).

Mahasiswa tidak hanya akan mempertimbangkan aspek fungsional (nilai utilitarian) dari pengalaman pendidikan dan kenikmatan simbolik (nilai hedonic), tetapi juga aspek sosial (nilai relasional atau hubungan) yang dapat mengarah pada tingkat loyalitas yang lebih tinggi (Gallarza, Gil-Saura, \& Holbrook, 2011). Telah terbukti bahwa dimasukkannya nilai relasional atau hubungan, bersama dengan nilai utilitarian dan nilai hedonic, secara signifikan meningkatkan prediksi KHM serta RM, sehingga menjaga pelanggan untuk tetap berada dalam hubungan (Hashim \& Yasin, 2017). Oleh karena itu, penelitian ini berhipotesis bahwa nilai-nilai multi-stimulus mahasiswa, yaitu utilitas, hedonic dan relasional, memiliki pengaruh yang positif pada KHM dan RM dari instansi pendidikan tinggi mahasiswa (dalam hal ini adalah Universitas Bangka Belitung). H2: Nilai utilitas berpengaruh positif terhadap KHM; H3: Nilai hedonic berpengaruh positif terhadap KHM; H4: Nilai hubungan atau relasional berpengaruh positif terhadap KHM; H5: Nilai utilitas berpengaruh positif terhadap RM; dan H6: Nilai hubungan atau relasional berpengaruh positif terhadap RM.

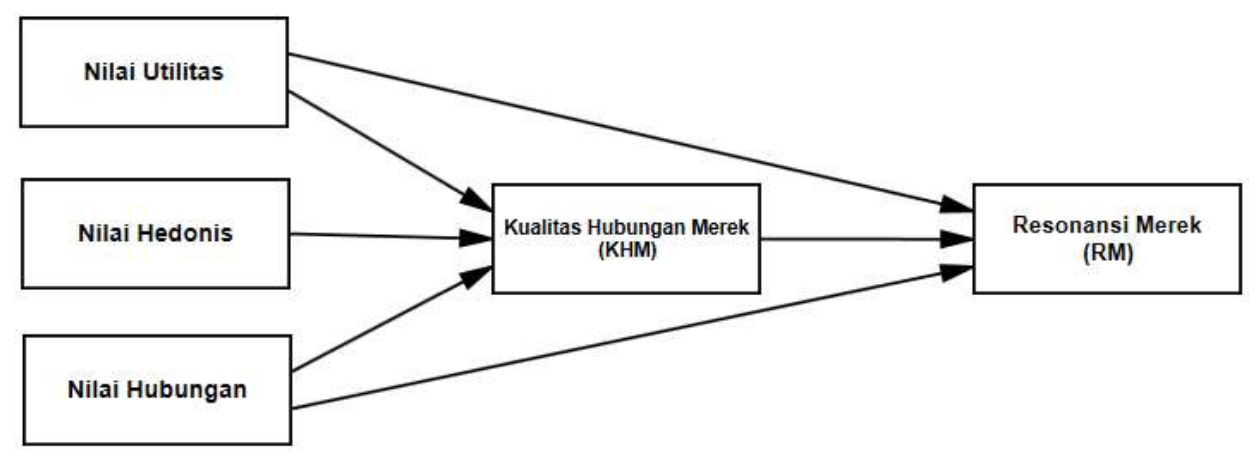

Gambar 1. Model Penelitian

Teori pertukaran sosial menunjukkan bahwa pertukaran tidak dapat dilakukan tanpa adanya peran sentral dari ikatan psikologis pelanggan untuk mengamankan hubungan antara nilai individu dan perilaku mereka terhadap objek atau merek (Zafirovski, 2005). Secara signifikan, setiap upaya yang mencoba untuk mengembangkan ikatan psikologis antara merek dan pelanggan kemungkinan akan menciptakan ikatan yang lebih besar dan respons serta loyalitas hubungan merek yang menguntungkan (Johnson, Herrmann, \& Huber, 2006). Ditambah dengan aspirasi, peran mediasi ikatan psikologis seperti KHM telah menerima dukungan besar di antara para sarjana pemasaran (misalnya Ou, Shih, Chen, \& Wang, 2011; Rajaobelina \& Bergeron, 2009; Sharizal \& Norjaya, 2012). Namun demikian, buktinya dalam konteks instansi pendidikan tinggi relatif tidak begitu populer. Oleh karena itu, penelitian ini menghipotesiskan peran Kualitas Hubungan Merek (KHM) dalam memediasi hubungan antara nilai-nilai pelanggan (Utilitas, Hedonic, Relasional atau Hubungan) dan RM. H7: KHM dapat memediasi nilai utilitas, nilai hedonic, nilai relasional, dan RM. Setelah membahas kerangka anteseden-mediasi-konsekuensi yang berkaitan dengan pembentukan Kualitas Hubungan Merek (KHM) di bawah konteks instansi pendidikan tinggi, penelitian ini menggambarkan hubungan sesuai dengan Gambar 1.

\section{METODE}

Survei dilakukan secara online terhadap mahasiswa Universitas Bangka Belitung menggunakan teknik sampel convenience sampling. Partisipasi bersifat sukarela, sehingga menghasilkan 250 responden, sebagai ukuran sampel pada penelitian ini. Selain berfokus pada 
branding dan legitimasi dalam bidang layanan, penelitian ini mempertahankan positivisme dan sikap paradigma hipotetis deduktif yang menekankan pada konstruksi objektif pembentukan KHM dalam konteks instansi pendidikan tinggi. Konteks instansi pendidikan tinggi dari penelitian ini selaras dengan Zakaria, Roslin, dan Daud (2011) yang mengklaim bahwa pendidikan telah menjadi salah satu kategori layanan yang menangkap fungsi mendasar dari pandangan layanan yang dominan. Proses pertukaran dan hubungan adalah sentral, di mana penciptaan nilai layanan hanya dapat dicapai melalui keterlibatan mahasiswa sebagai pelanggan (Wong \& Heng, 2009).

Untuk pengumpulan data, kuesioner yang dikelola sendiri dengan skala Likert 5 poin digunakan, dikembangkan dari indikator multi-item penelitian sebelumnya. Nilai utilitas berdasarkan item Quality, Price, dan Convenience (Kusumah, 2019; Seiders, Voss, Godfrey, \& Grewal, 2007). Nilai hedonic berdasarkan item brand awareness dan brand meaning (Sloot, Verhoef, \& Franses, 2005). Nilai hubungan atau relasional berdasarkan item trust, bonding, mutual dependence, dan empathy (Yau, McFetridge, Chow, Lee, Sin, \& Tse, 2000). Kualitas Hubungan Merek (KHM) berdasarkan item Commitment (Wu, 2011), yearning (Breivik \& Thorbjørnsen, 2008), dan liking (Wojciszke, Abele, \& Baryla, 2009). Resonansi Merek (RM) berdasarkan item loyalty (Fullerton, 2005), community sense (Cicognani, Pirini, Keyes, Joshanloo, Rostami, \& Nosratabadi, 2008), dan active engagement (Cavanagh, 2011). Penyesuaian kuesioner didasarkan pada umpan balik yang diperoleh dari pra survei 30 mahasiswa Fakultas Ekonomi Universitas Bangka Belitung untuk memeriksa tingkat keyakinan kuesioner.

Aplikasi Smart PLS digunakan untuk menilai model struktural dan hipotesis. Berkenaan dengan model pengukuran, nilai Average Variance Extracted (AVE) melebihi nilai yang direkomendasikan 0,5 (Hair, Hult, Ringle, \& Sarstedt, 2014), dimana menunjukkan validitas konvergensi yang cukup dari item pengukuran yang diusulkan. Selain itu, nilai Composite Reliability (CR) disarankan berada di atas nilai 0,6-0,7 dan nilai untuk loading factor diatas 0,5, seperti yang disarankan oleh Hair, Hult, Ringle, dan Sarstedt. (2014). Lebih lanjut, evaluasi validitas diskriminan menggunakan metode Fornell dan Larcker untuk menghasilkan nilai pembobotan yang lebih tinggi dari akar kuadrat AVE (ditunjukkan dalam diagonal) dibandingkan dengan nilai dalam baris dan kolom. Sebelum pengujian model dan hipotesis, profil responden sederhana diterapkan dengan item pertanyaan mengenai umur dan jenis kelamin.

\section{HASIL DAN PEMBAHASAN}

Hasil

Terdapat 247 kuesioner yang dapat digunakan untuk analisis lebih lanjut, sedangkan 3 kuesioner lainnya tidak dapat dilanjutkan karena jawaban yang tidak rasional dalam profil responden. Mayoritas responden berjenis kelamin perempuan (54\%) sedangkan laki-laki (46\%). Sementara umur responden berkisar antara 17-21 tahun, dimana semuanya masih berstrata satu (S1). Tabel 1 menunjukkan nilai AVE melebihi nilai CR menunjukkan bahwa item pengukuran berada di atas nilai yang disarankan 0,6-0,7 serta nilai untuk loading factor diatas 0,5 (Hair, Hult, Ringle, \& Sarstedt, 2014). Sedangkan pada Tabel 2, menunjukkan nilai validitas deksriminan (Fornell-Lacker method) yang baik dimana nilainya lebih besar daripada nilai akar kuadrat AVE (ditunjukkan dalam diagonal). Dengan demikian, semua pengukuran memiliki tingkat kehandalan yang memuaskan sebagaimana pada Gambar 2.

Untuk memperkirakan model struktural, prosedur bootstrap dengan 1000 sampel dijalankan. Hasilnya dapat dilihat pada Tabel 3 , di mana nilai adjusted $\mathrm{R}^{2}$ dapat diamati sebagai nilai utilitas, nilai hubungan, dan nilai hedonic yang menunjukkan 65,9\% varians dalam KHM. Di sisi lain, ketiga nilai tersebut, bersama dengan KHM berkontribusi $79,5 \%$ dari varians dalam RM. Tabel 4 menunjukkan bahwa semua koefisien jalur beta positif dan signifikan secara statistik dalam arah yang diharapkan (pada $\mathrm{p}<0,01)$. Pengaruh positif dan signifikan dari nilai utilitas ke KHM $(\beta=$ $0,134, \mathrm{p}<0,01)$, nilai hedonic ke KHM $(\beta=0,556, \mathrm{p}<0,01)$, nilai hedonic ke RM $(\beta=0,193, \mathrm{p}<$ $0,01)$, nilai hubungan ke KHM $(\beta=0,203, p<0,01)$, dan nilai hubungan ke $\mathrm{RM}(\beta=0,135, \mathrm{p}<$ $0,01)$. Dengan demikian, hipotesis 2, 3, 4, 5 dan 6 (H2-H6) dapat diterima. Demikian pula, KHM 
menunjukkan hubungan yang positif dan signifikan terhadap $\mathrm{RM}(\beta=0,634, \mathrm{p}<0,01)$, yang berarti hipotesis $1(\mathrm{H} 1)$ dapat diterima.

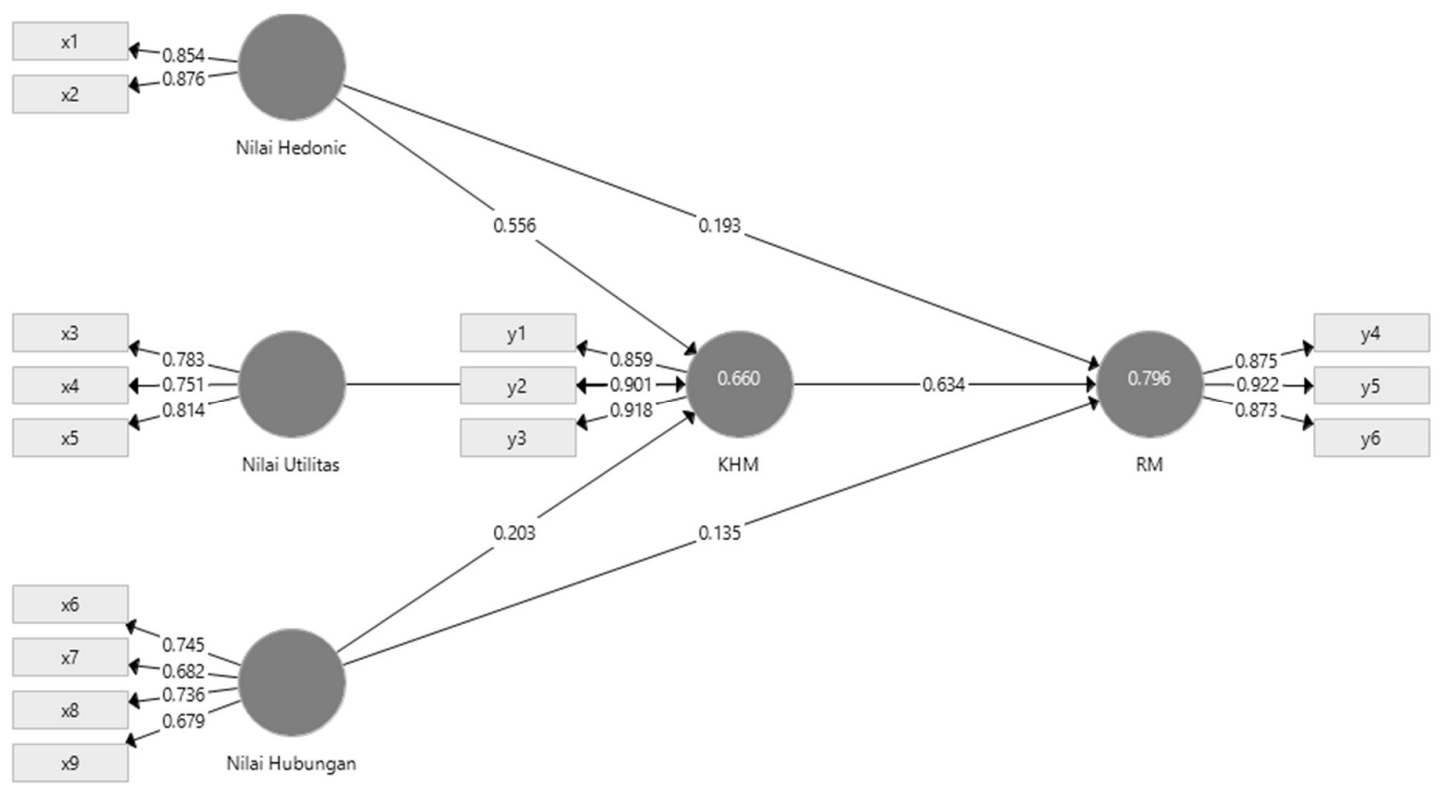

Gambar 2. Hasil Analisis Data

Tabel 1. Loading Factor, Validitas, dan Reliabilitas

\begin{tabular}{|c|c|c|c|c|}
\hline & Indicator & Loading Factor & $\mathrm{CR}$ & AVE \\
\hline \multirow[t]{3}{*}{ KHM } & Commitment & 0,859 & & \\
\hline & Passion & 0,901 & 0,922 & 0,798 \\
\hline & Liking & 0,918 & & \\
\hline \multirow[t]{2}{*}{ Nilai Hedonic } & Brand awareness & 0,854 & & \\
\hline & Brand meaning & 0,876 & 0,856 & 0,748 \\
\hline Nilai Hubungan atau & Trust & 0,745 & & \\
\hline \multirow[t]{3}{*}{ Relasional } & Bonding & 0,682 & & \\
\hline & pEmpathy & 0,736 & 0,803 & 0,505 \\
\hline & Mutual dependence & 0,679 & & \\
\hline \multirow[t]{3}{*}{ Nilai Utilitas } & Price & 0,783 & & \\
\hline & Service quality & 0,751 & 0,826 & 0,613 \\
\hline & Service convenience & 0,814 & & \\
\hline \multirow[t]{3}{*}{ RM } & Loyalty & 0,875 & & \\
\hline & Active engagement & 0,922 & 0,92 & 0,793 \\
\hline & Community sense & 0,873 & & \\
\hline
\end{tabular}

Sumber: Output Smart PLS

Hasil juga mengungkapkan bahwa nilai hedonic adalah prediktor yang lebih kuat dari nilai utilitas dan nilai hubungan. Pengaruh tidak langsung terhadap hipotesis ke-7 (H7), mengungkapkan bahwa efek tidak langsung nilai utilitas ke RM berpengaruh positif $(\beta=0,134 * 0,634=0,085)$ dan signifikan $(\mathrm{p}<0,01)$, nilai hedonic ke RM berpengaruh positif $(\beta=0,193 * 0,634=0,122)$ dan signifikan $(\mathrm{p}<0,01)$, serta nilai hubungan ke RM berpengaruh positif $(\beta=0,203 * 0,634=0,129)$ dan signifikan $(\mathrm{p}<0,01)$. Oleh karena itu, kita dapat menduga bahwa KHM secara signifikan memediasi hubungan antara nilai utilitas, nilai hedonic, nilai hubungan, dan RM. Oleh karena itu, $\mathrm{H} 7$ dapat diterima. 
Tabel 2. Fornell Lacker Criterion

\begin{tabular}{cccccc}
\hline & KHM & Nilai Hedonic & $\begin{array}{c}\text { Nilai } \\
\text { Hubungan }\end{array}$ & Nilai Utilitas & RM \\
\hline KHM & 0,893 & & & & \\
Nilai Hedonic & 0,785 & 0,865 & & & \\
Nilai Hubungan & 0,657 & 0,652 & 0,711 & & \\
Nilai Utilitas & 0,676 & 0,725 & 0,688 & 0,783 & \\
RM & 0,874 & 0,779 & 0,677 & 0,696 & 0,89 \\
\hline
\end{tabular}

Sumber: Output Smart PLS

Tabel 3. Nilai $\mathrm{R}^{2}$ dan Adjusted $\mathrm{R}^{2}$

\begin{tabular}{ccc}
\hline & R Square & $R$ Square Adjusted \\
\hline KHM & 0,660 & 0,659 \\
RM & 0,796 & 0,795 \\
\hline
\end{tabular}

Tabel 4. Hasil Bootstrap (1000 Samples)

\begin{tabular}{cccccc}
\hline & $\beta$ & Mean & Std.dev & T-Statistics & P Values \\
\hline KHM -> RM & 0,634 & 0,635 & 0,026 & 24,073 & 0,000 \\
Nilai Hedonic -> KHM & 0,556 & 0,556 & 0,035 & 15,691 & 0,000 \\
Nilai Hedonic -> RM & 0,193 & 0,191 & 0,029 & 6,574 & 0,000 \\
Nilai Hubungan -> KHM & 0,203 & 0,201 & 0,032 & 6,397 & 0,000 \\
Nilai Hubungan -> RM & 0,135 & 0,136 & 0,021 & 6,31 & 0,000 \\
Nilai Utilitas -> KHM & 0,134 & 0,137 & 0,035 & 3,84 & 0,000 \\
\hline
\end{tabular}

Pembahasan

Penelitian ini menjelaskan proses pembentukan KHM dalam konteks institusi pendidikan tinggi publik di Universitas Bangka Belitung. Temuan penelitian ini mengungkapkan bahwa semua variabel prediktif memainkan peran penting dalam mengembangkan RM suatu instansi pendidikan tinggi. Selanjutnya, variabel-variabel pada penelitian ini mempengaruhi RM baik secara langsung maupun tidak langsung, melalui efek mediasi dari KHM. Temuan mengkonfirmasi hipotesis bahwa pengaruh nilai-nilai pelanggan yang terdiri dari nilai utilitas, nilai hedonic dan nilai hubungan atau relasional mungkin terdapat di KHM mahasiswa yang kemudian mempengaruhi perilaku persepsi merek mereka. Hubungan positif antara nilai-nilai pelanggan dan KHM serta antara KHM dan RM didukung oleh data. Teori pertukaran sosial juga tampak cocok dengan data yang menyiratkan pembentukan KHM, khususnya dalam jenis layanan stimulus mental seperti pendidikan tinggi. Sederhananya, dengan memenuhi harapan mahasiswa pada aspek nilai pengalaman belajar, dapat meningkatkan citra merek dan ikatan hubungan terhadap suatu universitas. Selain itu, pembentukan KHM yang diinvestasikan dengan baik juga dapat mempengaruhi perilaku persepsi merek mahasiswa.

Peneliti merek (brand) akan mendapatkan lebih banyak informasi dari studi ini, tentang peran mediasi KHM dalam konteks pembentukan RM di bidang layanan. Penelitian ini menunjukkan bahwa penyelidikan lebih lanjut dan eksplorasi ke dalam ikatan psikologis merek sebagai motivator utama untuk respons pelanggan dan merek mungkin menjadi berharga. Penelitian ini berkontribusi secara konseptual dengan mengembangkan kerangka kerja yang menggambarkan hubungan teoritis dan rasional dalam pembentukan KHM. Dimasukkannya nilai hubungan/relasional sebagai anteseden tambahan sangat penting karena nilai utilitas dan nilai hedonic memiliki keterbatasan dalam menjelaskan bagaimana pelanggan memandang dan mengevaluasi merek.

Oleh karena itu, kerangka yang diusulkan dalam penelitian ini memberikan pandangan yang lebih tentang pembentukan hubungan merek mahasiswa dan universitas. Selain itu, penelitian ini berkontribusi pada pengetahuan yang ada dengan mengintegrasikan teori pertukaran sosial untuk 
menjelaskan RM dalam konteks layanan pendidikan tinggi. Secara khusus, penelitian ini menunjukkan peran penting teori pertukaran sosial dalam menjelaskan hubungan yang terjadi di antara mahasiswa dan Universitas Bangka Belitung. Studi ini mengungkapkan bahwa mahasiswa mengembangkan hubungan mereka dengan universitas melalui pengaruh nilai utilitas, nilai hedonic dan nilai hubungan/relasional, yang pada gilirannya, mempengaruhi intensitas ikatan psikologis mereka dengan universitas. Hal tersebut sejalan dengan teori pertukaran sosial, yang menjelaskan perspektif timbal balik pelanggan dalam diskusi pertukaran sosial-ekonomi baru-baru ini.

Lebih penting lagi, temuan berkembang pada nilai-nilai pelanggan (anteseden) dan sifat psikologis pelanggan seperti KHM (mediator), dan RM (hasil merek), karena hal itu terbukti signifikan dalam hierarki proses pembentukan hubungan merek pelanggan khususnya dalam konteks intansi pendidikan tinggi di Universitas Bangka Belitung. Penelitian ini juga membangun hubungan yang signifikan secara positif antara KHM dan RM mahasiswa dengan institusi mereka, menunjukkan bahwa semakin baik keadaan psikologis mereka, semakin kuat pula respons persepsi merek mahasiswa. Efek mediasi KHM dalam nilai-nilai pelanggan dan hubungan RM juga ditemukan dalam penelitian ini. Temuan-temuan ini secara kolektif menawarkan wawasan berharga ke dalam teori dan pengetahuan merek (brand) yang diinfuskan oleh pelanggan. Hasilnya telah mengungkapkan beberapa implikasi manajerial. Sekarang ada kebutuhan untuk meninjau kembali nilai yang dirasakan mahasiswa dari model pembelajaran pendidikan tinggi saat ini, karena hal ini berkaitan untuk meningkatkan citra merek universitas di Indonesia.

Dalam membentuk permintaan dan persediaan baru di bawah pengaruh pasar modern, universitas dapat menyalurkan upaya mereka untuk mengembangkan infrastruktur dan program yang lebih baik (elemen utilitas dan hedonic), serta membangun nilai hubungan yang baik dengan mahasiswa. Selain itu, nilai relasional atau hubungan yang berasal dari domain interaksi sosial memainkan peran penting dalam mempertahankan pelanggan dan memperkuat hubungan bisnis. Oleh karena itu, dengan menawarkan cakupan yang luas dari nilai-nilai layanan, universitas tidak hanya akan mengatasi persaingan yang ketat tetapi juga mengurangi kesenjangan harapan para pemangku kepentingan saat ini dalam konteks layanan pembelajaran yang lebih tinggi.

\section{SIMPULAN}

Mekanisme pemantauan merek layanan yang lebih tepat untuk Universitas Bangka Belitung adalah dengan mempertimbangkan tingkat ikatan psikologis mahasiswa, seperti komitmen, kerinduan, dan keinginan mereka terhadap universitas mereka. Ini dapat membantu ahli strategi merek universitas memahami motivasi utama mahasiswa untuk menciptakan ikatan yang lebih besar dan respons hubungan yang baik. Pemahaman yang jelas tentang ikatan psikologis mahasiswa jauh lebih penting daripada yang kita pikirkan. Dengan roadmap merek yang dirancang dengan baik, universitas dapat menurunkan biaya rata-rata kesalahpahaman dan masalah salah interpretasi yang dapat menggagalkan upaya pengembangan citra merek universitas di masa depan. Selain itu, ahli strategi merek layanan perlu beralih dari loyalitas merek ke pandangan yang lebih luas tentang konstruk konsekuensi merek, seperti RM sebagai misi merek organisasi layanan mereka. Studi ini percaya bahwa RM mampu memberikan tolak ukur untuk menggambarkan respon merek dalam ekonomi berbasis pengalaman layanan saat ini. Hal ini karena RM berfokus pada hubungan pamungkas dan tingkat identifikasi yang dimiliki pelanggan dengan suatu merek. Melalui integrasi kesetiaan dengan rasa kebersamaan dan keterlibatan aktif, diyakini bahwa penelitian ini memberikan pemahaman dan pedoman yang berguna untuk membantu ahli strategi merek dalam menetapkan tujuan dan strategi yang tepat yang mampu mengarahkan universitas untuk menjadi merek yang kuat di dunia baik panggung akademik lokal dan global.

\section{DAFTAR PUSTAKA}

Anand, G., Ward, P. T., \& Tatikonda, M. V. (2010). Role of explicit and tacit knowledge in Six Sigma projects: An empirical examination of differential project success. Journal of Operations Management, 28(4), 303-315. doi:https://doi.org/10.1016/j.jom.2009.10.003 
Breivik, E., \& Thorbjørnsen, H. (2008). Consumer brand relationships: an investigation of two alternative models. Journal of the Academy of Marketing Science, 36(4), 443-472. doi:https://doi.org/10.1007/s11747-008-0115-Z

Brodie, R. J., Glynn, M. S., \& Little, V. (2006). The service brand and the service-dominant logic: Missing fundamental premise or the need for stronger theory?. Marketing Theory, 6(3), 363379. doi:https://doi.org/10.1177/1470593106066797

Cavanagh, M. (2011). Students' experiences of active engagement through cooperative learning activities in lectures. Active Learning in Higher Education, 12(1), 23-33. doi:https://doi.org/10.1177/1469787410387724

Cicognani, E., Pirini, C., Keyes, C., Joshanloo, M., Rostami, R., \& Nosratabadi, M. (2008). Social participation, sense of community and social well-being: A study on American, Italian and Iranian university students. Social Indicators Research, 89(1), 97-112. doi:https://doi.org/10.1007/s11205-007-9222-3

Dollinger, M., Lodge, J., \& Coates, H. (2018). Co-creation in higher education: Towards a conceptual model. Journal of Marketing for Higher Education, 28(2), 210-231. doi:https://doi.org/10.1080/08841241.2018.1466756

Fleischman, D., Raciti, M., \& Lawley, M. (2015). Degrees of co-creation: an exploratory study of perceptions of international students' role in community engagement experiences. Journal of Marketing for Higher Education, 25(1), 85-103. doi:https://doi.org/10.1080/08841241.2014.986254

Fullerton, G. (2005). How commitment both enables and undermines marketing relationships. $\begin{array}{llll}\text { European Journal Of } & \text { Marketing, }\end{array}$ doi:https://doi.org/10.1108/03090560510623307

Gallarza, M. G., Gil-Saura, I., \& Holbrook, M. B. (2011). The value of value: Further excursions on the meaning and role of customer value. Journal of Consumer Behaviour, 10(4), 179-191. doi:https://doi.org/10.1002/cb.328

Goi, C. L., \& Goi, M. T. (2009). Rebranding of higher educational institutions in Malaysia. International Journal of Business and Management, 4(9), 170-177.

Graham, J. M. (2011). Measuring love in romantic relationships: A meta-analysis. Journal of Social and Personal Relationships, 28(6), 748-771. doi:https://doi.org/10.1177/0265407510389126

Hair, J., Hult, G. T., Ringle, C., \& Sarstedt, M. (2014). A primer on partial least squares structural equation modeling (PLS-SEM). California, CA: Sage.

Hashi, S., \& Yasin, N. M. (2017). The impact of relational value towards customer-brand relationship stickiness in the context of Malaysian public higher education service. International Journal of Business and Society, 18(2). doi:https://doi.org/10.33736/ijbs.544.2017

Jayawardhena, C. (2004). Personal values' influence on e-shopping attitude and behaviour. Internet Research, 14(2), 127-138. doi:https://doi.org/10.1108/10662240410530844

Johnson, M. D., Herrmann, A., \& Huber, F. (2006). The evolution of loyalty intentions. Journal of Marketing, 70(2), 122-132. doi:https://doi.org/10.1509/jmkg.70.2.122

Klassen, M. L. (2002). Relationship Marketing on the Internet: The case of top-and lower-ranked US Universities and Colleges. Journal of Retailing and Consumer Services, 9(2), 81-85. doi:https://doi.org/10.1016/S0969-6989(01)00028-5

Kusumah, E. P. (2019). Respon konsumen tentang kualitas pelayanan, penerimaan teknologi "tracking system" dan harga pada industri jasa pengiriman. Jurnal Ilmiah Bisnis dan Ekonomi Asia, 13(2), 111-118. doi:https://doi.org/10.32812/jibeka.v13i2.146 
Kusumah, E. P., Hurriyati, R., \& Dirgantari, P. D. (2019). Atribut Pemilihan Kualitas Restoran: Citra Merek dan Harga. Jurnal Bisnis dan Manajemen, 6(2), 117-126. doi:https://doi.org/10.26905/jbm.v6i2.3689

Mitchell, M. S., Cropanzano, R. S., \& Quisenberry, D. M. (2012). Social exchange theory, exchange resources, and interpersonal relationships: A modest resolution of theoretical difficulties. In Handbook of Social Resource Theory (pp. 99-118). Springer, New York, NY. doi:https://doi.org/10.1007/978-1-4614-4175-5 6

Mitchell M. S., Cropanzano R. S., Quisenberry D. M. (2012). Social exchange theory, exchange resources, and interpersonal relationships: A modest resolution of theoretical difficulties. In: Törnblom, K., \& Kazemi, A. (eds.) Handbook of Social Resource Theory. Critical Issues in Social Justice. Springer, New York, NY. doi:https://doi.org/10.1007/978-1-4614-4175-5 6

Ou, W. M., Shih, C. M., Chen, C. Y., \& Wang, K. C. (2011). Relationships among customer loyalty programs, service quality, relationship quality and loyalty. Chinese Management Studies, 5(2), 194-206. doi:https://doi.org/10.1108/17506141111142825

Rajaobelina, L., \& Bergeron, J. (2009). Antecedents and consequences of buyer-seller relationship quality in the financial services industry. International Journal of Bank Marketing, 27(5), 359-380. doi:https://doi.org/10.1108/02652320910979889

Robinson, N. M., \& Celuch, K. G. (2016). Strategic and bonding effects of enhancing the student feedback process. Journal of Marketing for Higher Education, 26(1), 20-40. doi:https://doi.org/10.1080/08841241.2016.1146386

Royo-Vela, M., \& Hünermund, U. (2016). Effects of inbound marketing communications on HEIs' brand equity: The mediating role of the student's decision-making process. An exploratory research. Journal of Marketing for Higher Education, 26(2), 143-167. doi:https://doi.org/10.1080/08841241.2016.1233165

Seiders, K., Voss, G. B., Godfrey, A. L., \& Grewal, D. (2007). SERVCON: development and validation of a multidimensional service convenience scale. Journal of the Academy of Marketing Science, 35(1), 144-156. doi:https://doi.org/10.1007/s11747-006-0001-5

Sloot, L. M., Verhoef, P. C., \& Franses, P. H. (2005). The impact of brand equity and the hedonic level of products on consumer stock-out reactions. Journal of Retailing, 81(1), 15-34. doi:https://doi.org/10.1016/j.jretai.2005.01.001

Sternberg, R. J., \& Sternberg, K. (Eds.). (2018). The new psychology of love. Cambridge University Press.

Teh, G. M., \& Salleh, A. H. M. (2011). Impact of brand meaning on brand equity of higher educational institutions in Malaysia. World, 3(2), 218-228.

Verghese, A., \& Kamalanabhan, T. J. (2015). Attributes influencing information search for College choice: An exploratory study. International Journal of Business Innovation and Research, 9(1), 34-51. doi:https://doi.org/10.1504/IJBIR.2015.065952

Wæraas, A., \& Solbakk, M. N. (2009). Defining the essence of a university: Lessons from higher education branding. Higher Education, 57(4), 449. doi:https://doi.org/10.1007/s10734-008$\underline{9155-\mathrm{Z}}$

Wojciszke, B., Abele, A. E., \& Baryla, W. (2009). Two dimensions of interpersonal attitudes: Liking depends on communion, respect depends on agency. European Journal of Social Psychology, 39(6), 973-990. doi:https://doi.org/10.1002/ejsp.595

Wong, E. S. K., \& Heng, T. N. (2009). Case study of factors influencing jobs satisfaction in two Malaysian universities. International Business Research, 2(2), 86-98.

Wu, L. W. (2011). Beyond satisfaction. Managing Service Quality: An International Journal. 
Wu, L. (2011). Beyond satisfaction: The relative importance of locational convenience, interpersonal relationships, and commitment across service types. Managing Service Quality: An International Journal, 21(3), 240-263. doi:https://doi.org/10.1108/09604521111127956

Yau, O. H., McFetridge, P. R., Chow, R. P., Lee, J. S., Sin, L. Y., \& Tse, A. C. (2000). Is relationship marketing for everyone?. European Journal of Marketing, 34(9-10), 1111-1127.

Zakaria, Z., Roslin, R. M., \& Daud, N. M. (2011). The influence of market orientation on the commitment, trust and relational norms in the education context. African Journal of Business Management, 5(22), 8875-8890. doi:https://doi.org/10.5897/AJBM11.291 